\title{
ON ENGLISH TRANSLATIONS OF R. M. RILKE'S POETIC LANGUAGE
}

\section{Natalia V. Voronevskaya \\ Associate Professor in the Department of English Language No 1 MGIMO University}

76, prospekt Vernadskogo Moscow, 119454, Russian Federation.nvoronevskaya@gmail.com

SPIN-code: $5973-5806$

ORCID: http://orcid.org/0000-0002-4039-0651

ResearcherID: I-3516-2017

Submitted 29.06.2020

\section{Просьба ссылаться на эту статью в русскоязычных источниках следующим образом:}

Voronevskaya N. V. On English translations of R. M. Rilke's poetic language // Вестник Пермского университета. Российская и зарубежная филология. 2021. Т. 13, вып. 2. С. 89-96. doi 10.17072/2073-6681-2021-2-89-96

Please cite this article In English as:

Voronevskaya N. V. On English Translations of R. M. Rilke's Poetic Language. Vestnik Permskogo universiteta. Rossiyskaya i zarubezhnaya filologiya [Perm University Herald. Russian and Foreign Philology], 2021, vol. 13, issue 2, pp. 89-96. doi 10.17072/2073-6681-2021-2-89-96 (In Russ.)

This study aims to assess the adequacy of the form of German sonnets when reproduced in English translations. The focus is on interrogative sentences, which, together with the sonnet in the form of a macrosentence, the shortened verse and enjambment, are the characteristics of the innovative features of Sonnets to Orpheus by R. M. Rilke. The lyrical cycle Sonnets to Orpheus is among the most translated into world languages of Rilke's poetry works, as well as Duino Elegies. Both professional and amateur poets and translators have been competing to put the Austrian writer's best poems into English. Here we examine more than twenty English translations of the Sonnets into English, made from 1936 to 2008. The importance of the comparative linguistic-stylistic study of the original and its translations is determined by the continuing interest in Rilke's works in English-speaking countries and the necessity to understand the principles of reconstructing the features of Rilke's poetics using the English language. The system of methods used in this work includes: historical and philological analysis, comparative linguistic and stylistic description, as well as comparative analysis of the original and translation in the form that was developed in the works of V. Bryusov (1905), N. Gumilev (1919), M. Lozinsky (1935), E. Etkind (1963), S. Goncharenko (1987). We have found that the innovative nature of German sonnets is not always reflected in English translations. In some translations, American and British translators significantly modified the form of the original: interrogative sentences dominating in XVII and XVIII sonnets of the second part of the lyric cycle were not reproduced in English translations made by G. Good, D. Young, C. Haseloff, N. Mardas Billias and others.

Key words: Rilke; sonnet; original; translation; syntax; German.

There has always been worldwide interest in Rainer Maria Rilke's (1875-1926) poetry and prose. For more than a hundred years, outside the Germanspeaking world Rilke has been best known in Russia, Great Britain and the United States of America [Huettich 1975: 121-128], [Jonas 1954: 55-59], [Benfey 1995: 112-123]. Traditionally, Rilke's later works: a unique and mysterious lyrical cycle "Sonnets to Orpheus" and the unsurpassed "Duino Elegies", both written by the Austrian poet in 1922, have attracted the attention of numerous Russian, British and American poets and translators. Rilke's poetry and prose were translated during Rilke's life time [Gass 1999: 25]. It is not unsurprising, therefore, that "Sonnets to Orpheus", for example, has been translated into English more than thirty times: the first English translation of a British poet J. B. Leishman dates from 1936, and the latest version of an American translator Cr. Marks was published in 2019. 
"Sonnets to Orpheus", fifty-five poems in two parts of the cycle, are devoted to deep philosophical issues that the poet was concerned with throughout his life: questions of life and death, being and creativity. In our opinion, the British researcher of Rilke, R. Cox, characterized the main topics of "Sonnets to Orpheus" and "Duino Elegies" in the most brilliant way: "In Das Studenbuch the silence which precedes the first poem is broken by the striking hour, summoning the world to the presence of the poet; in the Duineser Elegien by the cry of the poet, summoning the Angels to bear witness of the human condition; in the Sonette an Orpheus by the song of the god, creating a new order of silence, and summoning the poet to admiration. The first proposes a world open to the creative intervention; the second a world whose relatedness both with itself and the poet is dimly and fragmentarily perceived; the third a world of total relatedness before which the poet stands" [Cox 1979: 150].

But it is not only the poet's depth of thought that arouses continued interest among Rilke's fans around the world: foreign Rilke critics and translators have always pointed out an innovative renewal of the genre of sonnet as a solid form in Rilke's poetry: he changed classical sonnet's rhyme, meter, line lengths, as well as the canonical sonnet syntax. In our opinion, Scottish poet and translator of Rilke D. Paterson described the original sonnet form of the cycle best: " $<\ldots>$ as the Sonnets themselves also constitute a kind of meta-essay on the possibilities of the sonnet form, <..." [Paterson 2006: 62]. Further, D. Young, an American translator of Rilke, wrote that " $<\ldots>$ that the meaning and the expressiveness of these poems are completely bound up with the possibilities of their form, the sonnet and its larger manifestation, the sonnet sequence; no translator can afford to ignore that fact" [Young 1987: xiv].

It is well known that in poetry translation it is important to convey the content of the poetic original inextricably linked with its form. It is generally believed that to translate both poetic content and form into a foreign language accurately and completely is unthinkable. However, we propose that when translating any poetry into a foreign tongue, a translator should strive to honor not only the content of the poetic original but also its form as far as the native language allows him with as few deviations from the original as possible. The aim should always be to achieve the greatest degree of aesthetic equivalence of the original, both in content and form, to express its cultural and historical appearance to the reader in another country.

In our opinion, the main task of the translator is to preserve the linguistic identity of the original author as much as possible. The means for this should be the linguistic identity of the translator themselves, which refracts the author's linguistic personality through themselves and uses their creative potential in order to fully recreate the features of the author's idiolect in the translation, where domestication is possible. In some cases is even desirable and necessary, since, in addition to the interests of the author, the translator must take into account the recipients of the translation. Regarding this, P. Ricoeur said: "To translate is to serve two masters, the foreigner in his strangeness, the reader in his desire for appropriation" [Ricoeur 2006: 22-23]. How successful the translation will be depends on the ability of the translator to balance the interests of the author of the original and the reader of the translation, to resolve the internal conflict between his creative "I" and the need to eliminate it.

From our analysis of English translations of the Sonnets we conclude that, very often, Englishspeaking translators do not pay enough attention to how the form of the poetic original is regarded in the tradition, to which the original belongs, and, unfortunately, the knowledge of a foreign language is not a prerequisite for a poetry translator in the UK or the USA. Considering the peculiarities of the translation of Rilke's "New Poems" and "Duino Elegies" into English, American critic D. Frail emphasized: " $<\ldots>$ in recent decades, one might $<\ldots>$ point to an increasing popularity (or at least acceptance) of the abandonment of rigid standards for rhyme and meter" [Frail 1933: 392].

However, despite prevailing tradition in American and British poetic translation not to translate the formal signs of a verse (for example, rhyme and meter) [McNeil 2007: 24], [Hunter 1993: vii] some English-speaking translators suppose that the rhyme and size of the verse should be recreated in the translation of poetry at all costs [Moffet 1989: 145]. According to D. Paterson, if a translator follows the path of creating a rhymed transposition of the original ("especially for languages with a poor rhyme system"), then he will inevitably face the problem of "changing some aspect of the content" [Paterson 2006: 80]. Similarly, in the preface to his translations of the Sonnets, British poet and translator of Rilke, L. Norris, wrote about the importance of maintaining the form of the poetic original: " $<\ldots$..> this long poem ("Sonnets to Orpheus". - N. V.) is written as a sequence of sonnets, a very deliberate choice of form. To ignore this is to ignore much of the poem" [Norris 1989: vii]. Likewise, the renowned American poet and translator of Rilke, $\mathrm{W}$. Barnstone, the author of a monograph on the theory and practice of translation, is also an advocate of translation of rhymed poetry by rhymed verses: " $<\ldots>$ if one disapproves of rhyme in poetry, then one should not translate poems that rhyme" [Barnstone 1984: 50]. 
We strongly agree that the poetic form of any original in general, and of the Sonnets in particular, acts as the key to understanding the artistic picture of the poet's world: the combination of life and death as the opposites of a single being. The sonnet genre, like no other poetic form, underlines the principle of combining opposites, and, therefore, as S. Eom points out, Rilke's creation of the Sonnets in the sonnet form is not an accident [Eom 1988: 109], and therefore, the form of such individually modified sonnets should be undoubtedly reflected in translations into foreign tongues.

In this study we examine "Sonnets to Orpheus", in particular how syntactic features of the Sonnets' form are rendered into English, namely, numerous interrogative sentences on which XVII and XVIII sonnets of the second part of the cycle are almost entirely built. Interrogative sentences together with the sonnet in the form of a macro sentence, a shortened string and enjambemants belong to the main elements of Rilke's innovation in the field of syntax, and, therefore, should be taken into account when translating the Sonnets into English. To achieve our aim, we examined more than twenty English translations of the Sonnets made between 1936 and 2008.

"Sonnets to Orpheus" and "Duino Elegies" are acknowledged to be closely interconnected. XVII and XVIII sonnets of the second part of the Sonnets are devoted to the allegorical topic of "fruits of comfort" and dance, respectively. These sonnets can be perceived as a kind of continuation of "Duino Elegies". The gardens depicted in XVII sonnet, where the "fruits of comfort" are ripe, are like a mirror image of the Land of Suffering "with a positive sign" from "Duino Elegies". The angels of the "Elegies" as the embodiment of absolute spirituality incomprehensible to human consciousness, as it is written in the Second Elegy, endowed with frightening beauty, appear in XVII sonnet as inhabitants of gardens resembling Arcadia, and the sonnet, as a whole piece, can be read as a description of blessed countries. In the first quatrain of XVII sonnet we read: Wo, in welchen immer selig bewässerten Gärten, an welchen / Bäumen, aus welchen zärtlich entblätterten Blüten-Kelchen / reifen die fremdartigen Früchte der Tröstung?... (Rilke 1997: 97). Undoubtedly, this peculiar and complex interrogative sentence, which occupies three lines of the quatrain and contains two enjambemants, should be preserved In English translations. To illustrate the attempts of the Englishspeaking translators to display the syntactic features of the original we quote the following examples from their translations:

Herter Norton: Where, in what ever-blessedly watered gardens, on what trees, out of what tenderly unleaved blossom-calyxes do the exotic fruits of consolation ripen? ... (Rilke 1992: 103)

Lemont: $\quad$ Where, in what blessedly-watered gardens, on what trees Out of what tenderly unleaved bloom, Do the exotic fruits of consolation ripen? ... (Rilke 1945: 45)

MacIntyre: $\quad$ Where, in whatever-happily watered garden, on what trees, from what tenderly stripped flower-calices ripen the strange fruits of consolation? ... (Rilke 1960: 89)

Poulin: $\quad$ Where, in what heavenly watered gardens, in what trees, from what lovingly unsheathed flower-calyxes do the strange fruits of consolation ripen? ... (Rilke 1977: 171)

Mitchell: $\quad$ Where, inside what forever blissfully watered gardens, upon what trees, out of what deep and tenderly unpetaled flower-cups, do the exotic fruits of consolation hang ripening? ... (Rilke 1993b: 83)

Young: $\quad$ In what watered, ever-blissful gardens? On what trees? From what flower-goblets, gently stripped of petals, do these exotic fruits of consolation ripen? ... (Rilke 1987: 89)

Norris / Keele: In what gardens, watered always by heaven, on which trees, out of what soft revelation of calyxes, do the exotic fruits of consolation ripen? ... (Rilke 1989: 44)

Hunter: $\quad$ Where, in what blessed garden of eternally flowing waters, on what trees, in the cups of which tenderly leafless flowers, ripen those exotic fruits of consolation? (Rilke 1993a: 129) 

Mardas Billias: Tell me, in which of the gardens with water blessed, on which trees, within the chalice of which flower, gently stripped of leaves, does the rare fruit of solace ripen? ... (Rilke 2008: 44)

Snow: $\quad$ Where, in what ever blissfully watered gardens, on what branches, out of what tenderly un-petaled flower cups, do the exotic fruits of consolation ripen? ... (Snow 2005b: 93)

Good: $\quad$ Where, in what happily watered gardens, on what trees, among what gently falling blossom-chalices, ripen the exotic fruits of consolations? ... (Rilke 2004a: 101)

Furtak: $\quad$ Where, in what blissfully-watered gardens, on which trees, from what soft opening blossoms do the wild fruits of solace ripen? ... (Rilke 2007: 75)

Barnstone: $\quad$ Where, in what blissful watered gardens, in what trees, out of what tenderly unpetaled calyxes do the exotic fruits of consolation ripen? ... (Barnstone 2004b: 189)

Landman: $\quad$ Where, in which always blissful watered garden, on which trees, from which terderly-stripped-of-petals blossomcalices ripen the exotic fruits of relief? ... (Rilke 2020a: 28)

Leishman: $\quad$ Where, in what ever-blissfully watered gardens, upon what trees, out of, oh, what gently dispetalled flower-cups do these so strange-looking fruits consolation mature? (Rilke 1946: 121)

Pitchford: $\quad$ Where, in what forever mercifully drenched gardens, in what trees, out of what defoliated bud-calyxes, once so delicate, do they rare fruits of compassion ripen? ... (Rilke 1981: 43)

Cohn: $\quad$ Where, in what delightful ever-watered gardens, borne on what trees, grown of what softly-dispetalled calyces do the exotic fruits of Consolation ripen? ... (Rilke 2002: 101)

Paterson: $\quad$ Where, in what blessed, endlessly irrigated gardens, on what trees, from what delicately unpetalled calyces do the fruits of solace ripen? (Rilke 2006: 47)

Speirs: $\quad$ Where, in whichever blissfully watered gardens, on which Trees, and out of which tenderly unpetaled flower cups Do they ripen, the strange fruits of consolation? ... (Rilke 1965: 431)

Haseloff: $\quad$ Where does it ripen, that strange, awkward, invaluable fruit which they call solace? In what eternally lush gardens, on what trees, in what delicately wilted blossoms? (Rilke 1979: 42)

These examples show all translators attempted to retain Rilke's rhetorical question format. In fact, the three rhetorical questions in XVII sonnet of the second part of the Sonnets are fully preserved in almost all of the 20 translations examined (Poulin, Mitchell, Herter Norton, MacIntyre, Lemont, Haseloff, Mardas Billias, Norris (in cooperation with Keele), Hunter, Snow, Furtak, Barnstone, Landman, Young, Leishman, Pitchford, Cohn, Paterson and Speirs).

In other lines of XVII sonnet, however, the greater variation appears. Poulin introduced one more interrogative sentence, which was absent in the original sonnet. In the original: ... Diese / köstlichen, deren du eine vielleicht in der zertretenen Wiese // deiner Armut findest. ... (Rilke 2002: 97) and in Poulin's translation: ... Those precious / fruits, one of which you find perhaps in the trampled field // of your poverty? ... (Rilke 1977: 171). Good changed the tone of the original, switching one interrogative sentence of the original into narrative; he was not able to save the syntactic drawing of the sonnet completely. In his translation there is no final interrogative sentence: The way we ripen too soon and decay, / we shadows and shades, cannot take away / the equanimity of those calm summers. (Rilke 2004a: 101), but Rilke used one in the original: $\mathrm{Ha}$ ben wir niemals vermocht, wir Schatten und Schemen, / durch unser voreilig reifes und wieder welkens Benehmen / jener gelssenen Sommer Gleichmut zu stören? (Rilke 1997: 97).

As can be seen from the above examples, almost all translators, to some degree, sought to convey 
sonnet instrumentation and preserve its syntactic pattern, and only two translators, Young and Haseloff, "violated" the syntax of the original, splitting one interrogative sentence into three and two, respectively. We consider their English versions as most loosely reflecting the syntactic features of the original: their interpretations of the original cannot be considered adequate, since most of Rilke's other English translators were able to recreate the syntactic drawing of the original.

Now we will consider XVIII sonnet of the second part of "Sonnets to Orpheus", which is almost entirely based on rhetorical questions. Describing the dancer and dance in XVIII sonnet, Rilke implicitly, at the level of metaphors, shows the equal involvement of nature and art in the metamorphoses that underlie everything. It is no accident that the rotation of the dancer's figure is likened in the sonnet to the so-called "tree of movement". This sonnet can be understood as a recreation of dance by means of a poetic word, achieved, inter alia, through the interweaving of alliterations and assonances, and, thus, like many other poems of the cycle, as a narrative about a poetic language.

The use of numerous interrogative sentences is a distinctive feature of the syntax of so-called "sonnet in the form of a question": for fourteen lines of the original, there are five interrogative and only two affirmative sentences: Tänzerin: $o$ du Verlegung / alles Verghens in Gang: wie brachtest du's dar. / Und der Wirbel am Schluß, dieser Baum aus Bewegung, / nahm er nicht ganz in Besitz das erschwungene Jahr? // Blühte nicht, dass ihm dein Schwingen von vorhin umschwärme, / plötzlich sein Wipfel von Stille? Und über ihr, / war sie nicht Sonne, war sie nicht Sommer, die Wärme, / diese unzählige Wärme aus dir? // Aber er trug auch, er trug, dein Baum der Ekstase. / Sind sie nicht seine ruhigen Früchte: der Krug, / reifend gesteift, und die gereiftere Vase? // Und in den Bildern: ist nicht die Zeichnung geblieben, / die deiner Braue dunkler Zug, / rasch an die Wandlung der eigenen Wendung geschrieben? (Rilke 1997: 98).

In ten of the twenty English translations of this sonnet, this syntactic feature of the original is retained. These ten translations are those of Herter Norten, MacIntyre, Poulin, Pitchford, Norris (in cooperation with Keele), Landman, Snow, Good, Furtak and Hills. At the same time Leishman and Young rendered only four interrogative sentences of the original, Lemont and Mitchell - three, Paterson two and Mardas Billias - one.

American translators: Hunter, Cohn and Barnstone retained the four interrogative sentences of the original, and, in our opinion, inexplicably added one question in their interpretations of the sonnet: Hunter and Cohn - in the beginning of the first tercet re- spectively: It bore fruit as well, it bore, your tree of rapture. / Aren't these its tranquil fruits? The pitcher shot through / with ripe shades, and the vase, more slow to mature? // (Rilke 1993a: 129), and And it bore fruit too, the tree of your rapture: / are not these things its inanimate harvest? - the pitcher / striped like a gourd, the vase even riper and richer? (Rilke 2002: 103). Barnstone - in the second tercet: Through the pictures, the drawing, can't we see / an obscure stroke shaping an eyebrow / quickly scrawled on the wall? The dancer's turn? (Rilke 2004b: 191), while in Rilke's sonnet interrogative sentences are absent in these positions.

By this measure, Mardas Billias translation of XVIII sonnet is the least adequate because, even though it gives a fairly accurate idea of the content of the original, it lacks the dramatic tension of Rilke's sonnet, since the translator uses only one interrogative sentence instead of five.

Of all the considered translations of XVIII sonnet of the second part of the book "Sonnets to Orpheus", in our opinion, the least successful is the translation of Mardas Billias, in which the syntactic features of the original were recreated to the least extent compared to other English versions: Sweet dancer, for a while your pose / held death at a distance: grace became a prayer. I In your last whirl a tree arose, / a tree of movement, gathering hard-won years // blazing, into a peak of stillness, coming / from out the swarming swirling as you turned, / and over all it was your sun, your summer, / your immeasurable heart that burned. II And yes, your tree of rapture bore fruit, bore / the banded jug, the fluted vase: these now / are its quiet fruits. But among them one more // vivid image: is there not still a mark, / inscribed in air, the contour of your brow / the coil and wheeling of its final torque? (Rilke(c): 45). Another unsuccessful English version of this sonnet is that of Paterson: And the images ... How the vision persists / of the dark stroke of your eyebrow, sketched so fast / on the blank page of the blur of your pale face - (Rilke 2006: 48). In our opinion, this translation is a very approximate solution as both form the interrogative sentence at the end of the sonnet and content are not reproduced. Rilke's lines: Und in den Bildern: ist nicht die Zeichnung geblieben, / die deiner Braue dunkler Zug, / rasch an die Wandlung der eigenen Wendung geschrieben? (Rilke 1997: 98) were very freely interpreted by Paterson.

Examining Rilke's innovations of the sonnet form in his "Sonnets", exclamatory sentences, as a peculiar feature of this lyrical cycle's syntax, should be considered when rendering the Sonnets into foreign languages. To illustrate, let us examine the final lines of II sonnet of the first part of the book: Wo sinkt sie hin aus mir? ... Ein Mädchen fast ... (Rilke 1997: 54) were translated into English in the following ways: 
Kinnell / Liebmann: Where does she sink to out of me? ... A girl almost ... (Rilke 2000: 149)

Leishman:

Herter Norton:

MacIntyre:

Poulin:

Bly:

Mitchell:

Lemont:

Landman:

Young:

Norris / Keele:

Mardas Billias:

Barnstone:

Snow:

Haseloff:
Sinking to where from me? ... Almost a maid ... (Rilke 1946: 37)

Whither is she sinking out of me? ... A girl almost ... (Rilke 1992: 19)

does she sink from me-where? ... A girl almost ... (Rilke 1960: 5)

Where does she shrink to from me? ... barely a girl yet ... (Rilke 1977: 87)

Where is she going to, as she sinks away ... a girl really ... (Rilke 1972: 3)

Where is she vanishing? ... A girl almost ... (Rilke 1993b: 6)

She sinks from me - where? Where? ... maid almost ... (Rilke 1945: 2)

To where / sinks she away from me? ... Almost a maid ... (Rilke 2020b: 28)

Where does she drain out of me? ... a girl, almost ... (Rilke 1987: 5)

Where does she fade from me? ... A girl, just ... (Rilke 1989: 2)

She sinks, falls from me ... where? ... a child no longer ... (Rilke 2008: 2)

Where has she vanished to? ... A girl almost ... (Rilke 2004b: 105)

I can feel her drifting off ... to where? ... A girl almost ... (Snow 2005b: 9)

Where does she fade from me? ... Almost a girl ... (Rilke 1979: 2)
As it can be seen from the quoted translations, Lemont's version is extremely expressive with the word "where" unnecessarily used twice. In our opinion, Young's version is devoid of Rilke's poeticism and lyricism: the use of the English verb "to drain" in the sentence describing the disappearance of the girl by this translator feels very inadequate, since it does not convey Rilke's sensitivity about the young girl's passing away. Lesser's translation is not the most effective English version of the examined sonnet: ...Even if she rises out of me, / she slips away, she sinks,... A girl almost ... (Rilke 1986a: 37) compared to Rilke's original: Wo sinkt sie hin aus mir? ... Ein Mädchen fast ... (Rilke 1997: 54). In addition, Lesser chose not to retain the interrogative sentence in the second tercet of the sonnet. Two American translators Good and Barrows (in cooperation with Macy) did not adequately interpret these lines either (respectively): Falling away from me ... Almost a girl ... (Rilke 2004a: 60) and: If I forget her, will she disappear? (Rilke 2005a: 69).

Our analysis of the English translations of the interrogative sentences of "Sonnets to Orpheus" showed, when transforming the original German syntactic structures of sentences into English, that some English-speaking translators tend to simplify these structures in their translations, and this eventually leads to some degree of semantic depletion of the original form in a foreign tongue. In this case, the main maxim of translation - the aspiration for identity - is neglected.

\section{Literary Sources}

In Praise of Mortality. Selections from Rainer Maria Rilke's Duino Elegies and Sonnets to Orpheus. Transl. and ed. by A. Barrows and J. Macy. New York, Riverhead Books, 2005a, pp. 65-137. (In Eng.)

Lesser R. A Preface: Ten Years Later. Between Roots: Selected Poems. Transl. by R. Lesser. Prince- ton, N. J., Princeton University Press, 1986a, pp. xixii. (In Eng.)

Paterson D. Orpheus. A Version of Rilke's Die Sonnet an Orpheus. London, Faber and Faber, 2006, pp. 3-59. (In Eng.)

Rilke R. M. Sonnets to Orpheus. Duino Elegies. Transl. by J. Lemont. New York, Fine Editions Press, 1945, pp. 1-63. (In Eng.)

Rilke R. M. Sonnets to Orpheus. The German text, with an English translation, introduction and notes by J. B. Leishman. London, the Hogarth Press, 1946, pp. 34-145. (In Eng.)

Rilke R. M. Sonnets to Orpheus. With English translations and notes by C. F. MacIntyre. Berkeley and Los Angeles, University of California Press, 1960, pp. 1-113. (In Eng.)

Rilke R. M. From Sonnets to Orpheus. Transl. by R. Speirs. An Anthology of German Poetry from Höderlin to Rilke in English Translation. Ed. by A. Flores. Gloucester, Mass, Peter Smith, 1965, pp. 429-430, pp. 431-432. (In Eng.)

Rilke R. M. Ten Sonnets to Orpheus. Transl. by R. Bly. San Francisco, Zephyrus Image, 1972. 14 p. (In Eng.)

Rilke R. M. Duino Elegies and the Sonnets to Orpheus. Transl. by A. Poulin, Jr. Boston, Houghton Mifflin Company, 1977, pp. 83-199. (In Eng.)

Rilke R. M. Sonnets to Orpheus. Transl. by Ch. Haseloff. Privately Printed. Brooklyn, The Print Center, 1979, 39 p. (In Eng.)

Rilke R. M. The Sonnets to Orpheus. Transl. by K. Pitchford. New York, The Purchase Press, 1981, pp. 1-29. (In Eng.)

Rilke R. M. Sonnets to Orpheus. Transl. by R. Lesser. Between Roots: Selected Poems. Rendered from German by R. Lesser with a note by R. Howard and a preface by R. Lesser. Princeton, N. J., Princeton University Press, 1986b, pp. 37-39. (In Eng.)

Rilke R. M. Sonnets to Orpheus. Transl. and with an introduction by D. Young. Widdletown, Wesleyan University Press, 1987, pp. 1-113. (In Eng.) 
Rilke R. M. The Sonnets to Orpheus. Transl. from the original German by L. Norris and A. Keele. London, Skoob Books Publishing, 1989, pp. 1-56. (In Eng.)

Rilke R. M. Sonnets to Orpheus. Transl. by M. D. Herter Norton. New York, W. W. Norton and Company, Inc., 1992, pp. 16-127. (In Eng.)

Rilke R. M. Duino Elegies. The Sonnets to Orpheus. Transl. by R. Hunter with 26 block prints by M. Hunter. Eugene, Hulogosi Communications, Inc., 1993a, pp. 83-143. (In Eng.)

Rilke R. M. The Sonnets to Orpheus. Transl., with an introduction by St. Mitchell. Boston, Shambhala Publications Inc., 1993b, pp. 1-108. (In Eng.)

Rilke R. M. Duineser Elegien. Die Sonette an Orpheus [Duino Elegies. Sonnets to Orpheus]. Stuttgart, Philipp Reclam, 1997, 155 S. (In Ger.)

Rilke R. M. Sonnets to Orpheus with Letters to a Young Poet. Transl. from German by St. Cohn. New York, Routlege, 2002, pp. 13-167. (In Eng.)

Rilke R. M. Rilke's Late Poetry: Duino Elegies, the Sonnets to Orpheus, and Selected Last Poems. Transl. with an introduction and commentary by Gr. Good. Vancouver, Ronsdale Press, 2004a, pp. 59-115. (In Eng.)

Rilke R. M. Sonnets to Orpheus. Transl. with an introduction by W. Barnstone. Boston and London, Shambhala, 2004b, pp. 103-213. (In Eng.)

Rilke R. M. Sonnets to Orpheus. Transl. by E. Snow. New York, North Point Press, 2005b, pp. 5-119. (In Eng.)

Rilke R. M. Sonnets to Orpheus: a New English Version. Transl. by R. A. Furtak; with a philosophical introduction. Scranton and London, University of Scranton Press, USA, 2007, pp. 35-87. (In Eng.)

Rilke R. M. Sonnets to Orpheus. Transl. by N. Mardas Billias. Unpublished translation (accessed 30.06.2008). (In Eng.)

Rilke R. M. Sonnets to Orpheus. Transl. by D. Hills. Available at: http://www.stanford.edu/ dhills/orpheus.pdf/ (accessed 15.01.2020a). (In Eng.)

Rilke R. M. Sonnets to Orpheus. Transl. by H. Landman. Available at: http://www.polyamory.org/ howard/Poetry/orpheus_index.html/ (accessed 15.01.2020b). (In Eng.)

The Essentail Rilke. Selected and transl. by G. Kinnell and H. Liebmann. New York, The Ecco Press, 2000, pp. 149-157. (In Eng.)

\section{References}

Barnstone W. Preferences in Translating Poetry. Translation: Literary, Linguistic, and Philosophical Perspectives. Ed. by W. Frawley, Newark, DE, University of Delaware Press, 1984, 50 p. (In Eng.)
Benfey Ch. Rilke in Amerika. Rilke-Rezeptionen [Rilke Reconsidered]. Ed. by Sigrid Bauschinger and Susan L. Cocalis. In cooperation with Karin Obermeier. Tübingen, A. Francke Veerlag Tübingen und Basil, 1995, pp. 111-125. (In Ger.)

Cox R. Figures of Transformation: Rilke and the Example of Valéry. London, The Institute of Germanic Studies, University of London, 1979. 203 p. (In Eng.)

Eom S.-E. Todesvertrautheit. Deutungen der Orpheus-Gestalt in Rilkes Dichtung [Interpretations of the Orpheus Figure in R. M. Rilke's Poetry]. Frankfurt a. M., Bern, New York, Paris, Verlag Peter Lang, 1988. 125 p. (In Ger.)

Frail D. Lost in Translation: Reading Rilke in English. Ottawa, National Library of Canada, 1993. 397 p. (In Eng.)

Gass W. Reading Rilke. Reflections on the Problems of Translation. New York, Basic books, 1999. 233 p. (In Eng.)

Huettich G. Rilke in Amerika: Gestern, heute, morgen. Rilke: Kleine Hommage zum 100. Geburstag [Rilke: Small Homage for the 100th Birthday]. München, Edition Text und Kritik, 1975, pp. 121128. (In Ger.)

Hunter R. Translator's Preface. Rilke R. M. Duino Elegies. The Sonnets to Orpheus. Transl. by Robert Hunter with 26 block prints by M. Hunter. Eugene, Hulogosi, 1993, pp. vii-viii. (In Eng.)

Jonas K. W. Rilke und Amerika. Etudes Germaniques [German Studies], 1954, vol. 9, pp. 55-59. (In Ger.)

McNeil Ch., McCarthy P. Introduction. Rilke R. M. The Book of Hours. Transl. by $\mathrm{Ch}$. McNeil and P. McCarthy. Mayfield, Agenda Editions, 2007, pp. 524. (In Eng.)

Moffet J. Playing Scrabble without a Board: On Formal Translation from the Swedish Translating Poetry. The Double Labyrinth. Ed. by D. Weissbort. Iowa City, University of Iowa Press, 1989, pp. 144161. (In Eng.)

Norris L. A. Note from Leslie Norris. Rilke R. M. Sonnets to Orpheus. Transl. from the original German by L. Norris and A. Keele. London, Skoob Books Publishing, 1989, pp. vii-viii. (In Eng.)

Paterson D. Afterword. A Version of Rilke's Die Sonnet an Orpheus. London, Faber and Faber, 2006, pp. 61-84. (In Eng.)

Ricoeur P. On Translation. Transl. by Eileen Brennan. London, New York, Routledge Taylor and Francis Gr., 2006. 46 p. (In Eng.)

Young D. Introduction. Rilke R. M. Sonnets to Orpheus. Transl. by David Young. Widdletown, Wesleyan University Press, 1987, pp. vii-Xv. (In Eng.) 


\section{ОСОБЕННОСТИ ПОЭТИЧЕСКОГО ЯЗЫКА \\ Р. М. РИЛЬКЕ В АНГЛИЙСКИХ ПЕРЕВОДАХ}

Наталья Викторовна Вороневская

канд. филол. н., доцент кафедры английского языка № 1

МГИМО МИД России

119454, Россия, г. Москва, просп. Вернадского, 76. nvoronevskaya@gmail.com

SPIN-код: 5973-5806

ORCID: ORCID: http://orcid.org/0000-0002-4039-0651

ResearcherID: I-3516-2017

Статья поступила в редакичюю 29.06.2020

Целью настоящей работы является определение степени адекватности воссоздания элементов авторски модифицированного синтаксиса «Сонетов к Орфею» Р. М. Рильке в английских переводах, выполненных в США и Великобритании с 1936 по 2008 г. В центре внимания настоящей работы находятся вопросительные предложения, которые вместе с сонетом-макропредложением, укороченной строкой и стихотворным переносом (анжабеманом) являются основными элементами новаторства Рильке в форме классического сонета. Актуальность сопоставительного лингвостилистического изучения оригинала и его переводов определяется постоянным интересом к творчеству Рильке в англоязычных странах и необходимостью изучения принципов воссоздания особенностей поэтики Рильке средствами английского языка. Система методов, использованных в работе, включает: метод историко-филологического анализа и метод сопоставительного лингвостилистического описания, а также метод компаративного анализа оригинала и перевода в том его виде, который разработан в работах В. Я. Брюсова (1905 г.), Н. С. Гумилева (1919 г.), М. Л. Лозинского (1935 г.), Е. Г. Эткинда (1963 г.), С. Ф. Гончаренко (1987 г.). Определено, что новаторский характер немецких сонетов не всегда находит свое отражение в английских переводах. В некоторых переводах американские и британские переводчики в значительной мере модифицировали форму оригинала: вопросительные предложения, доминирующие в XVII и XVIII сонетах второй части лирического цикла, не были воссозданы в переводах на английский язык, выполненных Гр. Гудом, Д. Янгом, Ч. Хейзелоффом, Н. Мэрдас Биллиас и др.

Ключевые слова: Рильке; сонет; оригинал; перевод; синтаксис; английский язык. 